
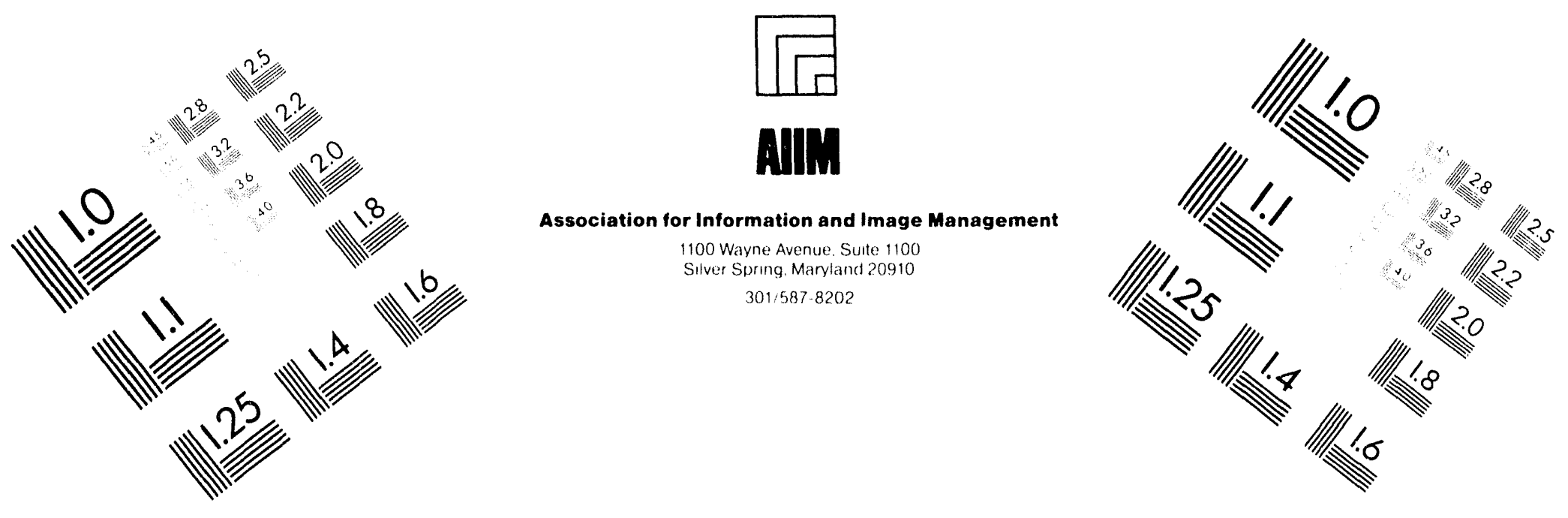

\title{
Centimeter
}

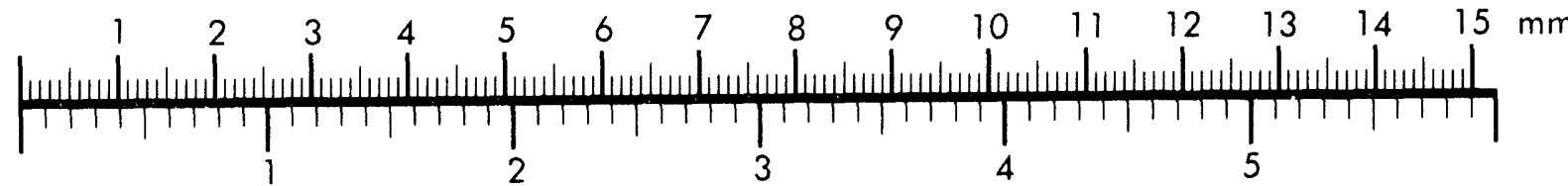

Inches
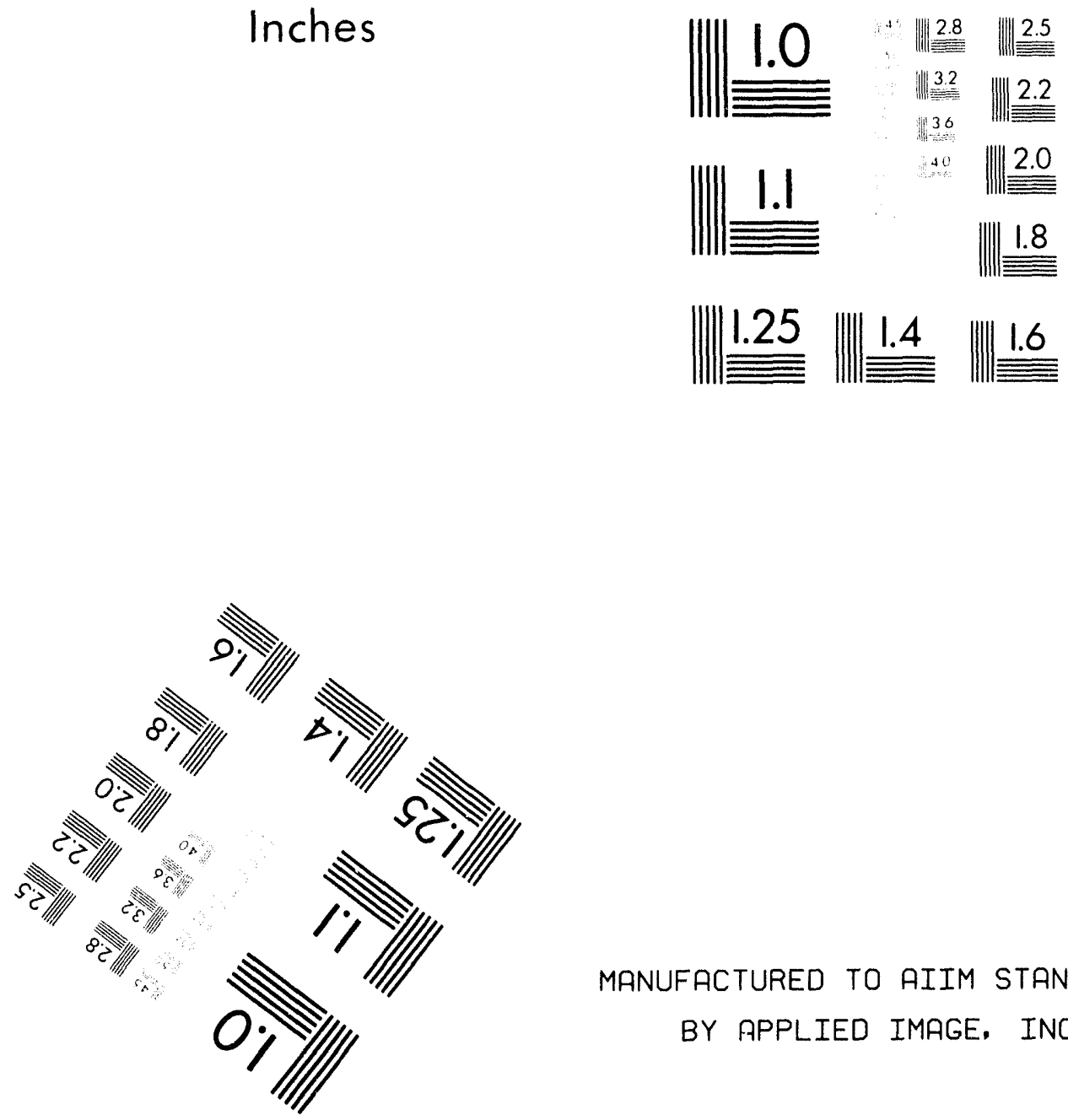

MANUFACTURED TO AIIM STANDARDS

BY APPLIED IMAGE. INC.

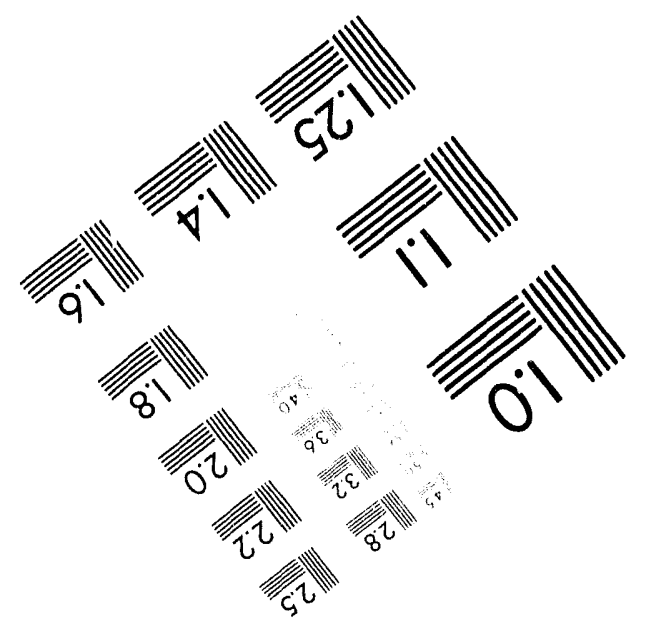



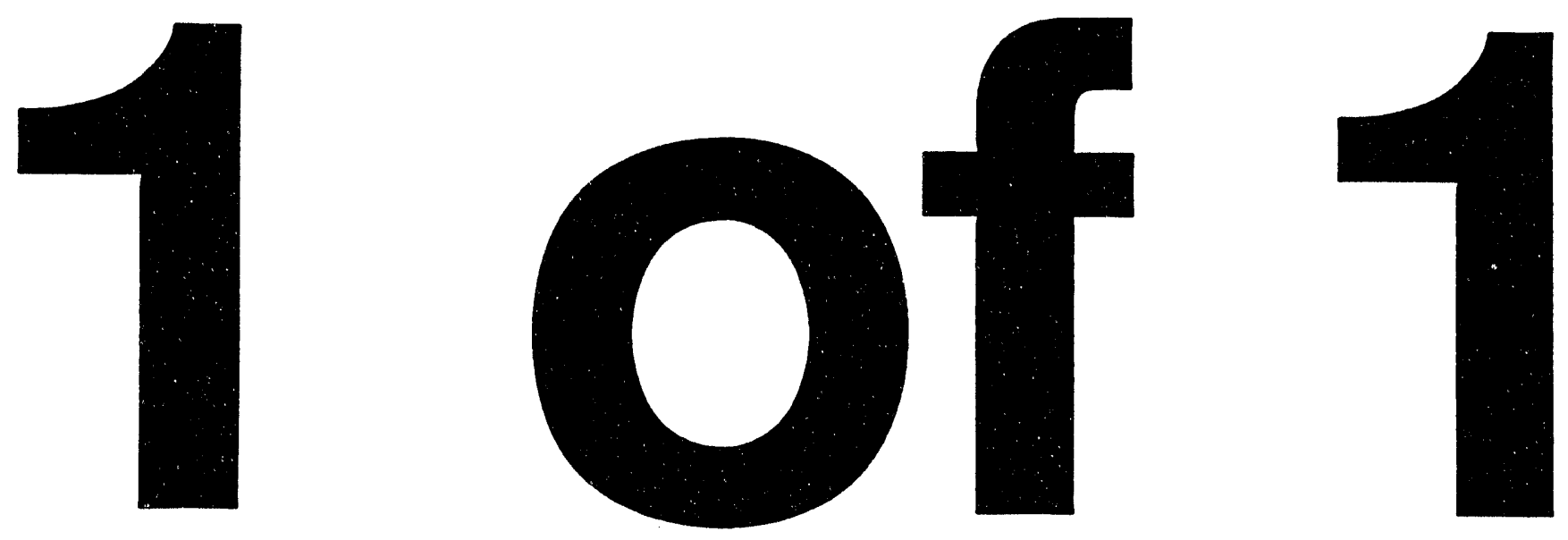


\section{COAL ASH RESOURCES RESEARCH CONSORTIUM}

Annual Report and Selected Publications

July 1, 1992, through June 30, 1993

Cooperative Agreement No. DE-FC21-93MC30098

Joint Venture Task 18

Prepared for:

Dr. Jerry L. Harness

U.S. Department of Energy

Morgantown Energy Technology Center

PO Box 880, M.S. E02

Morgantown, WV 26507-0880

and

Mr. Ray Davis, Brett Admixtures, Inc.

Mr. Andrew Stewart, Cooperative Power Association

Ms. Linda Pieper, Northern States Power Company

Mr. Ward Uggerud, Otter Tail Power Company

Mr. L.E. (Tex) Leber, Nebraska Ash Company

CONSORTIUM

Debra F. Pflughoeft-Hassett

Bruce A. Dockter

Kurt E. Eylands

David J. Hassett

Erin M. O'Leary

Energy \& Environmental Research Center

University of North Dakota

PO Box 9018

Grand Forks, ND 58202-9018

94-EERC-03-8

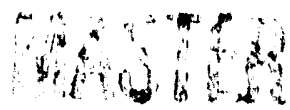

rp 


\section{TABLE OF CONTENTS}

LIST OF TABLES $\ldots \ldots \ldots \ldots \ldots \ldots \ldots \ldots \ldots \ldots \ldots \ldots \ldots \ldots$

EXECUTIVE SUMMARY $\ldots \ldots \ldots \ldots \ldots \ldots \ldots \ldots \ldots \ldots \ldots \ldots$

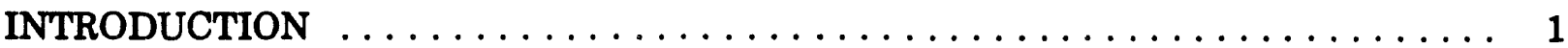

CARRC Industrial Members $\ldots \ldots \ldots \ldots \ldots \ldots \ldots \ldots \ldots \ldots \ldots \ldots$

CARRC Research Staff $\ldots \ldots \ldots \ldots \ldots \ldots \ldots \ldots \ldots \ldots \ldots \ldots$

REVIEW OF CARRC $1992-1993$ ACTIVITIES $\ldots \ldots \ldots \ldots \ldots \ldots \ldots \ldots \ldots$

Research and Laboratory Tasks $\ldots \ldots \ldots \ldots \ldots \ldots \ldots \ldots \ldots \ldots \ldots \ldots$

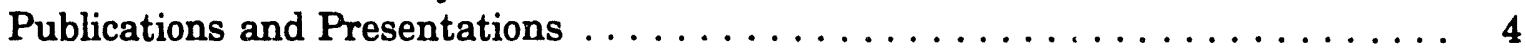

SUMMARIES OF RESEARCH AND LABORATORY ACTIVITIES $\ldots \ldots \ldots \ldots \ldots \ldots$

Coal Ash Properties Database Maintenance and Expansion . . . . . . . . 7

Investigation of the High-Volume Use of Fly Ash for Flowable Backfill

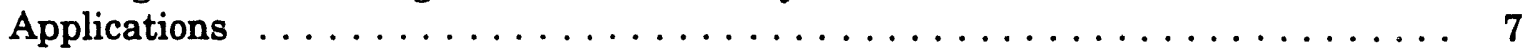

Investigation of Hydrated Mineralogical Phases in Coal Combustion By-

Products ................................ 8

Comparison of Department of Transportation Specifications for Coal Ash

Utilization $\ldots \ldots \ldots \ldots \ldots \ldots \ldots \ldots \ldots \ldots \ldots \ldots \ldots$

Comparative Leaching Study of Coal Combustion By-Products and Competing

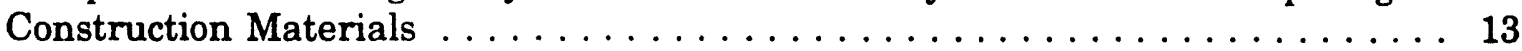

Application of CCSEM for Coal Ash Characterization . . . . . . . . . . . . 14

Determination of Types and Causes of Efflorescence in Regional Concrete

Products . . . . . . . . . . . . . . . . . . . . . . . . . . 19

Sulfate Resistance of Fly Ash Concrete: A Literature Review and Evaluation

of Research Priorities . . . . . . . . . . . . . . . . . . 20

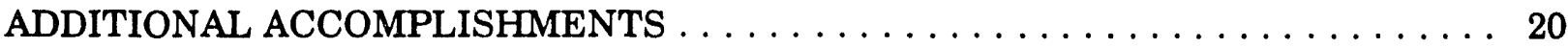

PLANNED ACTIVITIES FOR $1993-1994 \ldots \ldots \ldots \ldots \ldots \ldots \ldots \ldots$

LIST OF SELECTED PUBLICATIONS $\ldots \ldots \ldots \ldots \ldots \ldots \ldots \ldots \ldots \ldots$

SELECTED PUBLICATIONS $\ldots \ldots \ldots \ldots \ldots \ldots \ldots \ldots \ldots \ldots$ Appendix A 


\section{LIST OF TABLES}

1 Ettringite Formation in Hydrated CCSRs $\ldots \ldots \ldots \ldots \ldots \ldots$

2 Selenium and Boron Concentrations in Plain and Spiked CCSRs and in the

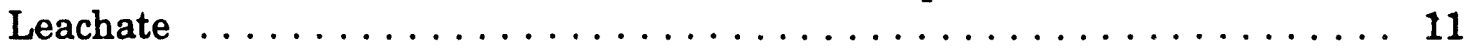

3 Mortar Bar Expansion, Unconfined Compressive Strength, XRD Ettringite

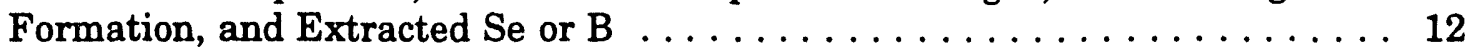

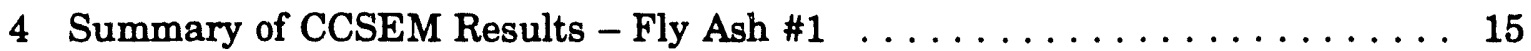

5 Summary of CCSEM Results - Fly Ash \#2 $\ldots \ldots \ldots \ldots \ldots \ldots \ldots$

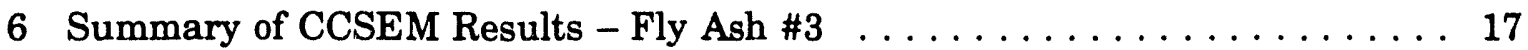

7 Summary of CCSEM Results - Fly Ash $\# 4 \ldots \ldots \ldots \ldots \ldots$ 


\section{COAL ASH RESOURCES RESEARCH CONSORTIUM}

\section{EXECUTIVE SUMMARY}

The Coal Ash Resources Research Consortium (CARRC, pronounced "cars"), formerly the Western Fly Ash Research, Development, and Data Center (WFARDDC), has continued fundamental and applied scientific and engineering research focused on promoting environmentally safe, economical use of coal combustion fly ash. The new name was chosen to more appropriately reflect the broadening scope of research performed through this consortium of member organizations, scientists, and engineers. CARRC member organizations are key to developing industry-driven research in the area of coal by-product utilization and ensuring its successful application, and a team approach is emphasized in every aspect of the research effort. As in the past, the CARRC research tasks were enhanced by a variety of complementary activities, including coal ash research projects funded from several different sources. CARRC researchers also participated in organizational activities of the American Coal Ash Association (ACAA) and the American Society of Testing and Materials (ASTM).

CARRC researchers worked with members to identify specific research topics of key interest to the coal ash industry. The research tasks selected for the year included 1) Coal Ash Properties Datábase Maintenance and Expansion, 2) Investigation of the High-Volume Use of Fly Ash for Flowable Backfill Applications, 3) Investigation of Hydrated Mineralogical Phases in Coal Combustion By-Products, 4) Comparison of Department of Transportation Specifications for Coal Ash Utilization, 5) Comparative Leaching Study of Coal Combustion By-Products and Competing Construction Materials, 6) Application of CCSEM for Coal Ash Characterization, 7) Determination of Types and Causes of Efflorescence in Regional Concrete Products, and 8) Sulfate Resistance of Fly Ash Concrete: A Literature Review and Evaluation of Research Priorities. The effort on sulfate resistance of fly ash concrete was cofunded by the ACAA. CARRC researchers also worked with regional construction and engineering companies and all levels of government agencies in promoting the utilization in proven engineering and construction applications. CARRC members were also active in many of these efforts, including a proposed project to use high-volume fly ash concrete in road paving projects, use of fly ash concrete in construction of the Energy \& Environmental Research Center (EERC) building additions, and changing University of North Dakota (UND) concrete specifications to include the use of fly ash. Local contractors were generally very cooperative in these efforts, and many good working relationships with associated industries were initiated.

The assembly of a database of information on coal fly ash has been a focus area for CARRC since its beginning in 1985. This year, CARRC members received an updated run time version of the Coal Ash Properties Database (CAPD) on computer disk for their use. The new, user-friendly database management format was developed over the year to facilitate the use of CAPD by members as well as CARRC researchers. It is anticipated that this direct access to CAPD by members will be beneficial to each company's utilization efforts, to CARRC, and to the coal ash industry in general. Many additions and improvements were made to CAPD during the year, and a three-year plan for computer database and modeling related to coal ash utilization was developed to guide both the database effort and the research effort. 


\section{COAL ASH RESOURCES RESEARCH CONSORTIUM}

\section{INTRODUCTION}

\section{CARRC Industrial Members}

The Coal Ash Resources Research Consortium (CARRC) depends on input from industrial members to design and develop a research program to address issues of interest to the coal by-products industry. CARRC members provide financial support to and are asked to participate in an advisory board to direct CARRC research. Input from CARRC members also facilitates the development of coal by-product-related research projects. The 1992-1993 members listed below are gratefully acknowledged for their participation and cooperation in CARRC research tasks and in other Energy \& Environmental Research Center (EERC) efforts:

Brett Admixtures, Inc.

Cooperative Power Association

Nebraska Ash Company

Northern States Power Company

Otter Tail Power Company

CARRC was also funded by the U.S. Department of Energy (DOE) Morgantown Energy Technology Center (METC) in 1992-1993 through the DOE Jointly Sponsored Research Program (JSRP) at the EERC. DOE's participation has been highly beneficial to the CARRC research staff and industrial members by providing matching funds for industrial contributions, technical input, and a direct link between DOE, utilities, and marketers.

\section{CARRC Research Staff}

The EERC's multidisciplinary approach to the research is well-demonstrated in CARRC research and related activities. CARRC has the opportunity to draw from the diverse research staff at the EERC while maintaining a core staff that focuses on coal byproduct utilization and disposal research. Key to this approach is communication among numerous individuals and groups as well as the coordination of sample identification, collection, distribution, and data manipulation. The individuals and research groups primarily responsible for the succ 3ss of CARRC are listed below.

Fuels and Materials Science

Steven A. Benson - Senior Research Manager

Bruce A. Dockter - Research Engineer

Kurt Eylands - Research Associate

Erin M. O'Leary - Information Technology Manager

Debra F. Pflughoeft-Hassett - Research Associate

Edward N. Steadman - Research Manager 
Applied Chemistry

David J. Hassett - Director

Jeffrey A. Forsberg - Research Chemist

Carolyn M. Lillemoen - Research Chemist

North Dakota State University

Gregory J. McCarthy - Professor of Chemistry and Geology

CARRC also employs and trains graduate and undergraduate students at the University of North Dakota (UND) and North Dakota State University (NDSU). In addition to providing valuable input to CARRC research and related activities, these students are knowledgeable and experienced in coal by-product utilization through their work with CARRC researchers and members as they move into technical and professional careers. CARRC researchers wish to acknowledge the following students for their role in advancing CARRC research during 1992-1993.

Graduate and Undergraduate Students

J. Solem-Tishmack, Graduate Student, Soils/Environmental Science, NDSU

J. Bender, Graduate Student, Chemistry, NDSU

L. Maianu, Undergraduate Student, Chemistry, NDSU

M. Oseto, Undergraduate Student, Chemistry, NDSU

J. Knell, Undergraduate Student, Chemistry, NDSU

J. Kreft, Undergraduate Student, Geosciences, NDSU

W. Heintz, Undergraduate Student, Mechanical Engineering, Engineering Management, UND

K. Kuhl, Graduate Student, Civil Engineering, UND

W. Gerszewski, Graduate Student, Civil Engineering, UND

M. Morris, Undergraduate Student, Chemical Engineering, UND

B. Bocht, Undergraduate Student, Civil Engineering, UND

P. Hatton, Undergraduate Student, Physics, UND

C. Prom, Undergraduate Student, Accounting, UND

L. Cava, Undergraduate Student, Civil Engineering, UND

G. Gustafson, Undergraduate Student, Civil Engineering, UND

Several EERC laboratory facilities and the associated technical staff play important roles in performing CARRC research. The laboratories most closely involved in CARRC research are listed below.

Laboratory Facilities

Analytical Research Laboratory

Coal Analysis Laboratory

Coal By-Products Utilization Laboratory

Materials Properties Research Laboratory

Natural Materials Analytical Research Laboratory 


\section{REVIEW OF CARRC 1992-1993 ACTIVITIES}

CARRC activities focused primarily on research tasks and coal ash utilization promotional activities. CARRC researchers developed several independent research proposals to address coal ash-related issues based on input from industry and DOE representatives. The EERC assembled information and prepared two documents on "Barriers to Increased Utilization of Coal Combustion/Desulfurization By-Products by Government and Commercial Sectors" under contract for DOE-METC to assist DOE in its obligation to Congress in this area. CARRC researchers were instrumental in accomplishing this effort and worked closely with CARRC members and representatives of other industrial and governmental groups during the effort. The CARRC research staff continued to work on American Society for Testing and Materials (ASTM) committees to develop appropriate standards for coal fly ash in use applications and contuiued participation in American Coal Ash Association (ACAA) committee work. Participation and committee work in these organizations is generically advantageous to the coal ash industry. The industrial financial support was again matched by the DOE through the JSRP, and a new option to perform coal ash research projects through CARRC and take advantage of DOE JSRP funds was initiated. Other coal by-products-related research projects continued at the EERC funded through various commercial and governmental organizations. Information gained through all coal by-products-related research adds to the information base of the CARRC, and ash characterization results are frequently available for inclusion in the CARRC database.

\section{Research and Laboratory Tasks}

The following CARRC research and laboratory tasks were performed and/or continued in 1992-1993:

- Coal Ash Properties Database Maintenance and Expansion

- Investigation of the High-Volume Use of Fly Ash for Flowable Backfill Applications

- Investigation of Hydrated Mineralogical Phases in Coal Combustion By-Products

- Comparison of Department of Transportation Specifications for Coal Ash Utilization

- Comparative Leaching Study of Coal Combustion By-Products and Competing Construction Materials

- Application of CCSEM for Coal Ash Characterization

- Determination of Types and Causes of Efflorescence in Regional Concrete Products

- Sulfate Resistance of Fly Ash Concrete: A Literature Review and Evaluation of Research Priorities 


\section{Publications and Presentations}

CARRC researchers published and presented results of CARRC research and other related research during the year. A list of all CARRC and related publications and presentations follows. Publications on CARRC research are presented in the "Selected Publications" section following the CARRC Annual Report. Other publications listed here may be obtained from the author or the EERC upon request. Additional Topical Reports are in preparation and will be made available to CARRC members only upon completion.

Bender, J.A. "Quantitative X-Ray Diffraction Analysis of Advanced Coal Combustion Solid Residuals and Ettringite Structure Phases," M.S. Thesis, North Dakota State University, Fargo, ND, 105 p.

Bender, J.A.; McCarthy, G.J.; Solem, J.K. "Quantitative Analysis of Advanced Coal Combustion Residuals by the Reference Intensity Ratio Method," Presented at the Denver Conference on Applications of X-Ray Analysis, Denver, CO, Aug. 3-7, 1992.

Bender, J.A.; Solem, J.K.; McCarthy, G.J.; Oseto M.C.; Knell, J.E. "Quantitative Analysis of Advanced Coal Combustion Residuals: A Practical Application of the RIR Method," Adv. X-Ray Anal. 1993, 36, 343-353.

Dockter, B.A. "Fluidized-Bed Combustion Waste: Utilization and Disposal," Presented at the Electric Power Research Institute Application of Fluidized-Bed Combustion for Power Generation Conference, Cambridge, MA, Sept. 23-25, 1992.

Dockter, B.A., Session Chair. "Environmental II," American Coal Ash Association Coal Ash Symposium Program, Orlando, FL, Jan. 17-23, 1993.

Dockter, B.A.; Manz, O.E. "Economic Feasibility of Producing Mineral Wool Fibers at a Coal Generation Power Plant," Presented at the American Coal Ash Association Coal Ash Symposium Program, Orlando, FL, Jan. 17-23, 1993.

Dockter, B.A.; Moretti, C.; Pieper, L.; Bluhm, S. "Development of Laboratory Methods for Evaluating the Erosion Resistance of Fly Ash-Based Materials," Presented at the American Coal Ash Association Coal Ash Symposium Program, Orlando, FL, Jan. 17-23, 1993.

Erickson, T.A.; O'Leary, E.M.; Folkedahl, B.C.; Ramanathan, M; Zygarlicke, C.J.; Steadman, E.N.; Hurley, J.P.; Benson, S.A. "Coal Ash Behavior and Management Tools," Presented at the Engineering Foundation Conference: The Impact of Ash Deposition on Coal Fired Plants, Solihull, UK, June 20-25, 1993.

Forsherg, J.A.; Hassett, D.J.; Pflughoeft-Hassett, D.F.; Lillemoen, C.M. "Comparative Leaching for Characterization of Cements and Cement Replacements (Fly Ash)," Presented at the Pittsburgh Conference, March 8-12, 1993.

Hassett, D.J.; Pflughoeft-Hassett, D.F. "Environmental Assessment of Coal Conversion Solid Residues," Presented at the American Coal Ash Association Coal Ash Symposium Program, Orlando, FL, Jan. 17-23, 1993. 
Hassett, D.J.; Pflughoeft-Hassett, D.F.; Lillemoen, C.M. "Long-Term Leaching to Predict Environmental Impacts of Coal Conversion Solid Residues (CCSRs)," Presented at the Pittsburgh Conference, March 8-12, 1993.

Manz, O.E. "Worldwide Production of Coal Ash and Utilization in Concrete and Other Products," Presented at the American Coal Ash Association Coal Ash Symposium Program, Orlando, FL, Jan. 17-23, 1993.

Manz, O.E., Session Chair. "International Perspectives," American Coal Ash Association Coal Ash Symposium Program, Orlando, FL, Jan. 17-23, 1993.

McCarthy, G.J.; Bender, J.A.; Solem, J.K.; Eylands, K.E. "Mineralogical Analysis of Advanced Coal Combustion Solid Residuals by X-Ray Diffraction," In Proceedings of the 10th International Ash Use Symposium; Palo Alto, CA, 1993; Electric Power Research Institute; EPRI TR-101774s, pp 58/1-14.

McCarthy G.J.; Hassett, D.J.; Bender, J.A. "Synthesis, Crystal Chemistry and Stability of Ettringite, A Material with Potential Applications in Hazardous Waste Immobilization," In Proceedings of the Materials Research Society Symposium: Advanced Cementitious Systems; 1992, Vol. 245, pp 129-140.

Pflughoeft-Hassett, D.F., Session Chair. "Environmental I," American Coal Ash Association Coal Ash Symposium Program, Orlando, FL, Jan. 17-23, 1993.

Pflughoeft-Hassett, D.F.; Dockter, B.A.; Hassett, D.J.; Beaver, F.W. "High-Volume Fly Ash Utilization and the Effects of Groundwater in North Dakota," Presented at the American Coal Ash Association Coal Ash Symposium Program, Orlando, FL, Jan. 17-23, 1993.

Pflughoeft-Hassett, D.F.; Hassett, D.J.; Lillemoen, C.M. "Comparative Leaching of Midwestern Coal Fly Ash and Cements," Presented at the American Coal Ash Association Coal Ash Symposium Program, Orlando, FL, Jan. 17-23, 1993.

Solem, J.K.; McCarthy, G.J. "Hydration Reactions and Ettringite Formation in Selected Cementitious Coal Conversion By-Products (High Calcium Fly Ash, Dry FGD Solids and FBC Residues)," In Proceedings of the Materials Research Society Symposium: Advanced Cementitious Systems; 1992, Vol. 245, pp 71-79.

Solem-Tishmack, J.K. "Use of Coal Conversion Solid Residuals in Solidification/ Stabilization Technology," M.S. Thesis, North Dakota State University, Fargo, ND, $173 \mathrm{p}$.

Steadman, E.N.; Eylands, K.E.; Folkedahl, B.C. "Advanced Methods of Ash Characterization - Using Detailed Characterization Techniques to Predict and Optimize Ash Utilization Properties," Presented at the American Coal Ash Association Coal Ash Symposium Program, Orlando, FL, Jan. 17-23, 1993.

Strobel, T.M., Session Chair. "Clean Coal Technology I," American Coal Ash Association Coal Ash Symposium Program, Orlando, FL, Jan. 17-23, 1993. 
Strobel, T.M.; Eylands, K.E.; Hassett, D.J.; Dockter, B.A.; Pflughoeft-Hassett, D.F. "Utilization Potentials for Duct Injection Residues," Presented at the American Coal Ash Association Coal Ash Symposium Program, Orlando, FL, Jan. 17-23, 1993.

Thompson, J.S.; Hassett, D.J. "The Use of Ion Exchange to Reduce Background and Spectral Interferences in the Analysis of Anions by Furnace Atomic Absorption and Inductively Coupled Argon Plasma Spectroscopy," Presented at the Pittsburgh Conference, Atlanta, GA, March 8-12, 1993.

CARRC researchers worked with other EERC and UND personnel, CARRC member representatives, representatives of state and federal agencies, and other industry groups and representatives in ash-related efforts throughout the year. Key activities included the following:

- CARRC researchers worked with other EERC personnel to provide information to DOE for a report to Congress on the barriers to the increased utilization of coal combustion and desulfurization by-products by government and commercial sectors.

- As an organizational member of ASTM, CARRC researchers participated in the ASTM E50 committee on Environmental Assessment. CARRC particifation focused on the E50.03 subcommittee's work on developing a standard guide for use of coal ash in structural fill and in initiating a task force to develop a standard coal ash leaching method. CARRC Consultant Mr. Oscar Manz participates on ASTM committees C1 on Cement, C7 on Lime, C9 on Concrete and Concrete Aggregates, D18 on Soil and Rock, and D34 on Waste Management and keeps CARRC researchers abreast of the actions of these committees. CARRC plans to extend its voting membership to include several of these committees.

- CARRC maintained its associate membership in ACAA and continued to participate in quarterly workshops and committee meetings throughout the year.

- CARRC researchers worked with UND and EERC administrators to initiate several fly ash concrete projects on the UND campus.

- CARRC researchers participated in a preliminary effort to form a coal ash promotional group in DOE Region 8.

- A Short Course entitled "Coal Ash Behavior and Deposition" was presented in conjunction with the ACAA Tenth Coal Ash Symposium, on January 22, 1993, in Orlando, Florida. This short course included presentations by CARRC researchers on coal ash utilization, disposal, and related environmental issues. Similar short courses are planned for 1993-1994 under the EERC-DOE Cooperative Agreement.

- The EERC was awarded a contract to perform a white paper study on the use of coal ash in waste solidification and stabilization. 
- CARRC members and researchers worked in conjunction with local contractors to obtain permission to place high-volume fly ash concrete pavement in road work in Grand Forks, ND. Grand Forks city engineers, North Dakota District Department of Transportation (DOT) engineers, and North Dakota State DOT offisials agreed that the project had merit; however, because of inflexibilicy in the project schedule and the time frame of the request, the project was not performed. CARRC researchers plan to continue to communicate with state DOT officials to develop a successful high-volume fly ash concrete paving project.

\section{SUMMARIES OF RESEARCH AND LABORATORY ACTIVITIES}

\section{Coal Ash Properties Database Maintenance and Expansion}

Formerly known as the Western Fly Ash Database, the Coal Ash Properties Database has undergone significant development during the year. The name has been changed to reflect the new name of the research group (CARRC) and to distinguish the extended nature of the database. The database is no longer limited to western coals and fly ash samples, but includes information on fly ash and other coal combustion byproducts from around the world. The primary sources of samples and information are the United States and Canada.

The development efforts this year focused on creating a database management system for interactive query and retrieval sessions. A user-friendly, menu-driven application was designed for the database. Interactive screens enable the user to view the information in a variety of formats. Statistical information can be generated, and information can be downloaded for use in reports or other computer programs. The application has been attached to a run-time version of the database management system as an executable version and distributed on floppy disks to CARRC members for operation on personal computers. A user manual was written and distributed with the database to CARRC members.

The database was enlarged with the addition of over 100 saraples and currently contains the physical, chemical, and mineralogical characteristics on more than 700 samples. Advanced characterization analysis was performed on a select group of samples. This information will be used to expand the database in the future.

In other database activities, we have initiated an internal tracking system for laboratory analysis to enable us to add samples to the database that are generated at EERC in related projects. Also, we are working on a system for gathering analytical information that is produced outside of EERC for inclusion in the database.

\section{Investigation of the High-Volume Use of Fly Ash for Flowable 'Backfill Applications}

The laboratory phase of this task to develop and compare mix designs for controlled low-strength materials was completed and presented to CARRC members. A Topical Report is in preparation and will be distributed to CARRC members in 1994. 


\section{Investigation of Hydrated Mineralogical Phases in Coal Combustion By- Products}

The overall objective of this research is to investigate the formulation, fabrication, and characterization of as-generated and compositionally modified coal residuals with a goal of increased utilization for engineered structures and in hazardous waste disposal. The specific objectives of the screening study are 1) to determine the baseline behavior of a selected group of coal residuals and explore compositional modification to improve behavior; 2) to describe the workability of the pastes during fabrication and determine the strength of the solidified residues and the amount of expansion during curing (potentially from the formation of ettringite); 3 ) to describe the crystal morphology and microstructure relevant to the hydration reactions (ettringite and $\mathrm{C}-\mathrm{S}-\mathrm{H}$ formation) and to immobilization of hazardous oxyanions; 4) to determine the amount of hydration products that form over time in as-generated and compositionally modified residuals.

Ettringite forms in cementitious systems any time materials contain high levels of calcium and sulfate, create a solution $\mathrm{pH}$ of about 12 , and include aluminum that can be solubilized at these pHs. These conditions are met in the case of some of the residuals from coal combustion by conventional processes, by most of the newer "clean cosl" (i.e., fluidized-bed combustion) processes, and by some flue glass desulfurir ation rosiduals. These are collectively referred to as coal combustion solid residuals (CCSR $\$$ ). Utilization of these residuals for engineered structures or hazardous waste disposal is a promising alternative to landfill disposal.

Previous investigations at the EERC and NDSU have demonstrated that crystallizing ettringite incorporates hazardous element oxyanions such as $\mathrm{SeO}_{4}, \mathrm{CrO}_{4}$, $\mathrm{B}(\mathrm{OH})_{4}$ and $\mathrm{AsO}_{4}$, which are the more mobile species of hazardous elements in coal residuals. Many of these cementitious residuails show promise for use in hazardous solid waste disposal. In another project, mineralogy, microstructure, and microchemistry development over time in the cores excavated from the three field test cells are being studied.

We report here the results of two multiinvestigator projects involving formulation and curing of CCSR-based test materials, strength and expansion tests on these materials, crystalline-phase and microstructure characterization, and leaching tests on boron- and selenium-spiked materials. In the first project, the extent of ettringite formation in ten CCSRs and four cements was surveyed. In the second project, selenium and boron were spiked into the mixing water used to solidify four of these CCSRs, and a leaching test was performed after 91 days of curing. This research was co-funded by the Gas Research Institute and DOE, whose principal interest was in the boron and selenium immobilization research. Work performed over a 3-year period was completed during the spring of 1993. Initial results were described in the previous annual report. The research formed part of the M.S. theses of Jody $K$. Solem-Tishmack and Jason A. Bender, which are available on request.

Selected CCSRs and four ccm nercial cements, as listed in Table 1, were hydrated under specific water-to-solid (w:s) ratios. The amount of ettringite formed after 91 days of room-temperature curing in a sealed container was determined by two separate quantitative XRD protocols developed during the course of this study (Table 1). Development and applications of these protocols were described in the previous annual 


\section{TABLE 1}

Ettringite Formation in Hydrated CCSRs

\begin{tabular}{lccc}
\hline & \multicolumn{3}{c}{ \% Etringite after 91 Days } \\
Hydrated CCSR & w:s & Protocol 1 & Protocol 2 \\
\hline Fly Ash & & & \\
Wyoming Subbituminous & 0.35 & 6 & 6 \\
North Dakota Lignite (low-Na) & 0.65 & 7 & 6 \\
North Dakota Lignite (high-Na) & 0.25 & 9 & 9 \\
Texas Lignite & 0.35 & 5 & 23 \\
Pennsylvania Bituminous & 0.53 & 24 & 1 \\
FGD Residual & 0.24 & 4 & 0 \\
Unconditioned & 0.30 & 0 & 20 \\
Conditioned & & & 18 \\
AFBC Residuals & 0.40 & 22 & 19 \\
Kentucky Bituminous Spent Bed & 0.50 & 18 & \\
Kentucky Bituminous Fly Ash/Char & 0.30 & 14 & 1 \\
Colorado Bituminous Fly Ash & 0.50 & & 22 \\
& 0.60 & 24 & 24 \\
LIMB Residual & 0.63 & 30 & 14 \\
\hline
\end{tabular}

${ }^{a}$ Results from a mixed peak height/peak area method.

${ }^{b}$ Results from an advanced profile-fit peak area method.

report. Except for the high-sodium North Dakota lignite fly ash, the pulverized coal fly ashes formed only minor amounts of ettringite, because their chemical compositions were sulfate-limited. The high-sodium ash was also high in sulfate (crystalline sodium sulfate was observed by $x$-ray diffraction analysis [XRD]), so this ash formed more ettringite. The Pennsylvania bituminous coal fly ash did not meet the criteria for formation of ettringite and was included only as a control sample. The flue gas desulfurization residual, the fly ash from the atmospheric fluidized-bed combustion processes, and the limestone injection multistage burner (LIMB) sorbent injection residue formed moderate amounts (15\%-30\%) of ettringite.

Based on the initial survey of ettringite formation, a more comprehensive screening study was designed. In addition to evaluating the immobilization potential for Se and B in CCSRs, additional tests (supported by cofunding) of expansion on curing and compressive strength were performed. Four of the CCSRs from the previous study were selected for further evaluation. The selection was based on the availability of these materials from operating power plants. The four CCSRs were as follows: 
- High-calcium fly ash from a midwestern U.S. power plant burning Powder River Basin, Wyoming, subbituminous coal. This material is typical of high-calcium ashes.

- North Dakota lignite low-sodium fly ash, which exhibits slow strength development itself, but is an effective pozzolan (uaterial that develops strength on hardening when activated by alkali) in concrece.

- A flue gas desulfurization (FGD) residue from a midwestern U.S. power plant burning Montana subbituminous coal. This plant uses a dry scrubber process that results in calcium sulfite hydrate instead of the more conventional calcium sulfate hydrate as the scrubber residual.

- An atmospheric fluidized-bed combustion (AFBC) fly ash from an eastern U.S. commercial power plant using a bituminous coal source. Some fine unburned coal residue (char) is included $w$, th the fine fly ash.

Standard ASTM methods were used for fabrication and testing: CCSR-water mixing, ASTM C305; paste flow determination, ASTM C230; paste curing, ASTM C511; mortar bar preparation, ASTM C151; compressive strength, ASTM C109. Specimens were fabricated into cubes and cured for 7,28 , and 91 days at $70^{\circ} \mathrm{F}$ in constant humidity relative humidity approximately $100 \%$ ). A plain sample without any added selenium and boron was prepared. For the spiked specimens, selenium (added both as sodium selenite and selenite) and boron (added as sodium borate) were included in the mixing water. Table 2 gives the selenium (Se) and boron (B) concentrations in the original dry CCSR and the hydrated solid after the spiked mixing water was incorporated into the paste.

Specimens cured for 91 days were ground $(<0.3 \mathrm{~mm})$ and leached at a water-to-solid ratio of 20:1 with deionized water. Sample bottles were inverted at $45 \mathrm{rpm}$ for 18 hours. The vigorous grinding and agitation steps were designed to ensure that there would be little or no contribution to immobilization from having tested a monolithic solid.

Concentrations of Se and B in the leachates are listed in Table 2. In Table 3, this concentration has been converted to a percent of the total Se or B extracted during the leaching test. Table 3 also gives the extent of expansion during curirig, compressive strength of the cubes, and the percent of ettringite formed in the cured solids, as determined by quantitative XRD analysis.

Some of the key observations from these tests follow:

- Expansion on curing the pastes was significant only for the FBC ash, where almost 3\% expansion was observed. In contrast, the plain FGD specimen actually showed a measurable contraction on curing.

- All four CCSR pastes were self-hardening; 91 day compressive strengths ranged from about $650 \mathrm{psi}(4.5 \mathrm{MPa}$ ) for the FBC ash to more than 4,000 psi (28 $\mathrm{MPa}$ ) for the high-calcium fly ash. 
TABLE 2

Selenium and Boron Concentrations in Plain and

Spiked CCSRs and in the Leachate

\begin{tabular}{|c|c|c|c|c|c|c|c|}
\hline \multirow[b]{2}{*}{ CCSR } & \multicolumn{2}{|c|}{$\begin{array}{l}\text { Original } \\
\text { CCSR, mg/kg }\end{array}$} & \multicolumn{2}{|c|}{$\begin{array}{l}\text { Total after } \\
\text { Spiking, mg/kg }\end{array}$} & \multicolumn{3}{|c|}{ Leachate Concentration, $\mathrm{mg} / \mathrm{L}$} \\
\hline & $\mathrm{Se}$ & B & $\mathrm{Se}$ & B & $\begin{array}{l}\text { Selenite } \\
\text { Spike }\end{array}$ & $\begin{array}{l}\text { Selenate } \\
\text { Spike }\end{array}$ & $\begin{array}{l}\text { Borate } \\
\text { Spike }\end{array}$ \\
\hline \multicolumn{8}{|c|}{ Subbituminous } \\
\hline FA & 12.5 & 1232 & 413 & 2032 & 0.64 & 2.20 & 1.40 \\
\hline \multicolumn{8}{|l|}{ Lignite } \\
\hline FA & 13.7 & 1829 & 414 & 2629 & 0.18 & 2.60 & 2.40 \\
\hline FGD & 7.6 & 1352 & 408 & 2152 & $-\cdots$ & 0.65 & 0.49 \\
\hline AFBC & 7.7 & 441 & 408 & 1241 & 0.04 & 2.90 & 0.25 \\
\hline
\end{tabular}

- All CCSRs formed ettringite on hydration, ranging from about 5\% ettringite for the two fly ash pastes to more than $30 \%$ for the AFBC flay ash paste, after 91 days of curing.

- Borate was the oxyanion most readily immobilized in the hardened pastes; the selenite $\left(\mathrm{SeO}_{2} 3^{-}\right.$)-spiked pastes had more immobile selenium than the selenite $\left(\mathrm{SeO}_{2} 4^{-}\right)$-spiked pastes.

- When ettringite formation in the cured pastes exceeded $20 \%$, boron was $99 \%$ immobilized according to the leaching test; even with only minor (6-10\%) ettringite formation, better than $93 \%$ of the selenium added as selenite and $70 \%$ of the selenium added as selenite were immobilized.

These results are consistent with the conclusion that ettringite formation has provided good Se and excellent B immobilization, at least for the duration of the leaching test.

\section{Comparison of Department of Transportation Specifications for Coal Ash Utilization}

One of the primary obstacles to fully capitalizing on the engineering properties of coal ash resources has been the lack of understanding of or familiarity with the different applications appropriate for coal ash. Understanding the properties of coal ash allows the design engineer to determine the best alternatives when prescribing material specifications. However, because of lack of resources, namely, time and funding, most transportation engineers cannot properly research all the current technologies for coal ash utilization. The primary objective of this task is to present a state-by-state comparison of DOT specifications governing the use of coal combustion residues. This compilation will allow transportation and materials engineers to become familiar with other department 
TABLE 3

Mortar Bar Expansion, Unconfined Compressive Strength, XRD Ettringite Formation, and Extracted Se or B

\begin{tabular}{|c|c|c|c|c|c|c|c|c|}
\hline \multirow{2}{*}{$\begin{array}{l}\text { CCSR } \\
\text { Spike } \\
\end{array}$} & \multicolumn{2}{|c|}{ Expansion, \% } & \multicolumn{2}{|c|}{$\begin{array}{l}\text { Compressive } \\
\text { Strength, psi }\end{array}$} & \multicolumn{3}{|c|}{ Ettringite, \% } & \multirow{2}{*}{$\begin{array}{c}\text { Extracted } \\
\text { Se/B, \% } \\
91 \mathrm{~d}\end{array}$} \\
\hline & $91 \mathrm{~d}$ & $7 \mathrm{~d}$ & $28 \mathrm{~d}$ & $91 \mathrm{~d}$ & $7 \mathrm{~d}$ & $28 \mathrm{~d}$ & $91 \mathrm{~d}$ & \\
\hline \multicolumn{9}{|c|}{ High-Calcium WY Subbituminous Coal pc Fly Ash (w:s $=0.25 ; 80 \%$ ash) } \\
\hline Plain & 0.00 & 3155 & 3735 & 3890 & 7 & 6 & 6 & \\
\hline Selenite & 0.01 & 3090 & 2700 & 3835 & 7 & 9 & 8 & 6.2 \\
\hline Selenate & 0.01 & 4723 & 4350 & 3190 & 7 & 7 & 4 & 21.3 \\
\hline Borate & 0.05 & 3055 & 3670 & 4445 & 15 & 12 & 11 & 2.8 \\
\hline \multicolumn{9}{|c|}{ ND Lignite (low-Na) pc Fly Ash (w:s $=0.17 ; 86 \%$ ash) } \\
\hline Plain & 0.01 & 570 & 590 & 1840 & 6 & 6 & 5 & \\
\hline Selenite & 0.00 & 625 & 460 & 1970 & 7 & 7 & 6 & 1.7 \\
\hline Selenate & -- & 430 & 750 & 1225 & 4 & 9 & 6 & 25.1 \\
\hline Borate & 0.04 & 755 & 925 & 4120 & 7 & 7 & 6 & 3.7 \\
\hline \multicolumn{9}{|c|}{ Dry Scrubber Ash/MT Subbituminous Coal (w:s $=0.45 ; 69 \%$ ash) } \\
\hline Plain & -0.12 & 230 & 415 & 670 & 20 & 19 & 22 & \\
\hline Selenite & --- & 265 & 410 & -- & 20 & 18 & -- & -- \\
\hline Selenate & -- & 275 & 605 & 655 & 22 & 22 & 21 & 6.4 \\
\hline Borate & 0.01 & 555 & 720 & 845 & 21 & 27 & 26 & 0.9 \\
\hline \multicolumn{9}{|c|}{ AFBC Fly Ash/Bituminous Coal (w:s $=0.45 ; 69 \%$ ash) } \\
\hline Plain & 2.86 & 520 & 1120 & 1245 & 15 & 20 & 32 & \\
\hline Selenite & -- & 360 & 875 & 1355 & 11 & 21 & 28 & 0.4 \\
\hline Selenate & 2.66 & 290 & 860 & 1455 & 12 & 21 & 21 & 28.5 \\
\hline Borate & 2.88 & 220 & 585 & 1060 & 12 & 27 & 33 & 0.8 \\
\hline
\end{tabular}

practices in the field of coal ash utilization. It is anticipated that technology development efforts may be reduced through this work.

A survey letter was sent to all highway department offices in the United States and Canada in August 1992. Specifications on the use of coal by-products in their construction procedures were requested. There were three main specification categories: 
- Physical and chemical coal by-product specifications

- Applications using coal by-products and the corresponding specifications

- Quantities of by-products allowed in each application

The response to the survey was excellent. The information obtained is presented in two separate formats. First, a series of tables is presented to allow a quick reference to specific areas and comparison of the different specifications. This facilitates evaluation of regulations and experiences in coal ash utilization by state or province. The second format is a text format presented for each individual state or province. The second format provides more detailed information concerning mix designs and departmental preferences and further clarifies application procedures. Both methods are intended to be used as a means for basic comparison, not as a comprehensive design manual.

The task has been completed, and a draft topical report has been prepared. Copies of the report have been sent to all transportation departments that participated in the survey. The information collected was updated during the course of the DOE barriers study performed by the EERC, so the topical report is being revised with editorial changes and will be available to CARRC members during the next year. Future work in this area will include regular updates to follow changes in transportation department practices as new technologies are explored and brought into use by transportation agencies.

\section{Comparative Leaching Study of Coal Combustion By-Products and Competing Construction Materials}

This activity focuses on the comparative leaching of coal combustion by-products and competing construction materials. The objective of the task is to provide leaching information on a wide variety of competing materials in the marketplace, allowing equitable evaluation of materials that may not be subject to the same environmental evaluation as coal combustion by-products. Examples of these materials are cement, aggregates, and a variety of fill materials. Several leaching procedures will be used, and this information, combined with the information already available from other EERC studies, will allow generalized statements of appropriateness of leaching procedures for utilization or disposal. It is anticipated that the scope of the task may be expanded to include leaching of products containing coal combustion by-products. Regional materials were selected for the first phase of this task.

During 1992-1993, comparative short- and long-term leaching experiments were completed on four regional, commercially available cements and four coal fly ash samples submitted from CARRC members. An appropriate suite of parameters, including the Resource Conservation and Recovery Act (RCRA) elements, was selected for evaluating the leachates from these experiments. Comparisons of the leaching results from coal fly ash samples and cements were presented for the ACAA Tenth International Ash Symposium. The formal cite for this paper is included in the List of Selected Publications section of this report. Short-term leaching results only were included in this paper to meet the submitted deadline. A graphical presentation of leaching results made to highlight key points was presented at the 1993 CARRC Annual Meeting. Results of the first phase of this task provide some specific examples of coal fly ash and cement that can be directly compared. A topical report of this phase of the task is in preparation and will be distributed to CARRC members in 1994. 
During 1993-1994, the leaching information and all other characterization information on the coal fly ash scimples will be placed into the Coal Ash Properties Database. Additional work proposed for 1993-1994 includes the leaching of concrete samples containing one of the cements from the first phase and each of the coal fly ash samples.

\section{Application of CCSEM for Coal Ash Characterization}

Automated scanning electron microscope/microprobe techniques are effective tools for tne characterization of complex materials such as coal and coal ash. Computer-controlled scanning electron microscopy (CCSEM) is used to cb aracterize unaltered coal samples and inorganir, combustion products. A computer program is used to locate, size, and analyze particles. Because the analysis is automated, a large number of particles can be analyzed quickly and consistently. The heart of the CCSEM analysis system is an annular backscattered electron detector (BSE). The BSE system is used because the coefficient of backscatter (the fraction of the incoming beam that is backscattered) is proportional to the square root of the atomic number of the scattering atoms. This permits a high degree of resolution between sample components based on their atomic numbers. This means that ash particles can be easily discerned from the epoxy matrix. Brightness and contras ${ }^{+}$ controls are used to optimize threahold levels between the coal matrix and mineral grains or fly ash particles. When a video signal falls between these threshold values, a particle is discerned and the particle center located. A set of eight rotated diameters about the center of the particle are measured, and the particle area, perimeter, and shape are calculated. The beam is then repositioned to the center of the particle, and an x-ray spectrum is obtained. The information is then stored to a transportable file for data reduction and manipulation on a PC. The CCSEM data provide quantitative information concerning not only the mineral types present, but their size and shape characteristics as well. Since the same analysis can be performed on the initial coal and resultant fly ash, direct comparisons can be made and inorganic transformations inferred.

CCSEM techniques provide valuable information, but this information can be even more useful when evaluated in conjunction with morphological observations and chemical analysis of the microstructural features of the material. This is performed using the SEM manually to scan across the samples. Imaging and elemental mapping can be performed.

It has long been known that coal fly ash particle size and surface area have a strong impact on the reactivity of these materials. Since CCSEM results indicate the particle size and the associated chemical composition of the various size fractions, it was proposed to perform a screening study to determine if correlations between the CCSEM results and various physical behaviors of coal fly ash could be made. Preliminary work included the selection of four coal fly ash samples that had been well characterized. The samples selected were used in the comparative leaching task. CCSEM analysis and morphologic observations were performed on each sample. The results are presented in Tables 4-7.

Tables 4-7 are the summary pages of CCSEM data. The mineral area data in the parameter summary are most useful for analysis of mineral matter in coal. For coal byproduct samples (e.g., fly ash), this information is not important except to know that a wide variety of particle sizes have been analyzed. Large particles fill the screen at high magnifications and cannot be sized or chemically typed. For coal by-product analyses, the total number of points analyzed is important. The more points analyzed, the more 
TABLE 4

Summary of CCSEM Results - Fly Ash \#1

SUMMARY OF PARAMETERS

TOTAL MINERAL AREA ANALYZED AT HIGH MAG NORMALIZED AREA ANALYZED AT HIGH MAG MINERAL AREA ANALYZED INTERMEDIATE MAG NORMALIZED AREA ANALYZED INTERMEDIATE MAC: TOTAL MINERAL AREA ANALYZED AT LOW MAG NUMBER OF FRAMES AT HIGH MAG NUMBER OF FRAMES AT INTERMEDIATE MAG NUMBER OF FRAMES AT LOW MAG TOTAL NUMBER OF POINTS ANALYZED NUMBER OF POINTS UNDER THRESHOLD

$=\quad 3289.1$

$=\quad 456943.8$

$=\quad 42522.5$

$=\quad 298607.8$

$=\quad 52598.6$

$=\quad 41$

$=\quad 76$

$=23$

$=\quad 2024$

$=6$

WEIGHT PERCENT ON A MINERAL BASIS

$\begin{array}{lllllll}1.0 & 2.2 & 4.6 & 10.0 & 22.0 & 46.0 & \\ \text { TO } & \text { TO } & \text { TO } & \text { TO } & \text { TO } & \text { TO } & \text { TO'I'ALS } \\ 2.2 & 4.6 & 10.0 & 22.0 & 46.0 & 100.0 & \end{array}$

\begin{tabular}{|c|c|c|c|c|c|c|c|}
\hline QUARTZ & 2.3 & 4.3 & 1.3 & 1.5 & .7 & .3 & 10.3 \\
\hline IRON OXIDE & .1 & .3 & 4 & .2 & .0 & .0 & 1.0 \\
\hline PERICLASE & .0 & .0 & .0 & .0 & .0 & .0 & .0 \\
\hline RUTILE & .1 & .0 & .0 & .0 & .0 & .0 & .1 \\
\hline ALUMINA & .0 & .0 & .0 & .0 & .0 & .0 & .0 \\
\hline CALCITE & .0 & .0 & .2 & .0 & .1 & .0 & .3 \\
\hline DOLOMITE & .0 & .0 & .1 & .4 & .2 & .0 & .8 \\
\hline ANKERITE & .1 & .0 & .0 & .2 & .0 & .0 & .3 \\
\hline KAOLINITE & .1 & .0 & .1 & .1 & .0 & .0 & .3 \\
\hline MONTMORILLONITE & .2 & .1 & .0 & .0 & .1 & .0 & .4 \\
\hline K AL-SILICATE & .9 & 3.1 & 2.7 & 1.6 & .5 & .6 & 9.4 \\
\hline FE AL-SILICATE & .0 & .2 & .0 & .1 & .1 & .0 & .4 \\
\hline CA AL-SILICATE & 6.7 & 9.2 & 5.1 & 1.5 & .6 & .0 & 23.0 \\
\hline NA AL SILICATE & .0 & .0 & .0 & .0 & .0 & .0 & .0 \\
\hline ALUMINOSILICATE & .0 & .1 & .1 & .3 & .2 & .0 & .6 \\
\hline MIXED AL-SILICA & .5 & .6 & .2 & .0 & .0 & .0 & 1.2 \\
\hline FE SILICATE & .0 & .0 & .0 & .0 & .1 & .0 & .1 \\
\hline CA SПICATE & .8 & .3 & .5 & .2 & .1 & .7 & 2.7 \\
\hline CA ALUMINATE & .0 & .0 & .0 & .0 & .0 & .0 & .0 \\
\hline PYRITE & .0 & .0 & .0 & .0 & .0 & .0 & .0 \\
\hline PYRRHOTITE & .0 & .0 & .0 & .0 & .0 & .0 & .0 \\
\hline OXIDIZED PYRRHO & .1 & .0 & .0 & .0 & .0 & .0 & .1 \\
\hline GYPSUM & .0 & .1 & .1 & .0 & .0 & .0 & .3 \\
\hline BARITE & .1 & .0 & .1 & .0 & .0 & .0 & .1 \\
\hline APATTTE & .0 & .0 & .0 & .0 & .0 & .0 & .0 \\
\hline CA AL-P & .0 & .0 & .0 & .0 & .0 & .0 & .0 \\
\hline KCL & .0 & .0 & .0 & .0 & .0 & .0 & .0 \\
\hline GYPSUM/BARITE & .0 & .0 & .0 & .0 & .0 & .0 & .0 \\
\hline GYPSUM/AL_SILIC & .4 & 1.8 & .8 & .3 & .0 & .0 & 3.2 \\
\hline SI-RICH & 2.5 & 3.4 & 3.1 & 1.6 & .7 & .0 & 11.2 \\
\hline CA-RICH & .0 & .0 & .2 & .1 & .0 & .0 & .3 \\
\hline CA-SI RICH & .3 & 1.1 & 3 & .6 & .1 & .0 & 2.5 \\
\hline UNKNOWN & 6.4 & 10.3 & 8.1 & 4.8 & 1.6 & .0 & 31.2 \\
\hline TOTALS & 21.5 & 34.8 & 23.7 & 13.5 & 5.0 & 1.6 & 100.0 \\
\hline
\end{tabular}


TABLE 5

Summary of CCSEM Results - Fly Ash \#2

SUMMARY OF PARAMETERS

TOTAL MINERAL AREA ANALYZED AT HIGH MAG NORMALIZED AREA ANALYZED AT HIGH MAG MINERAL AREA ANALYZED INTERMEDIATE MAG NORMALIZED AREA ANALYZED INTERMEDIATE MAG

TOTAI MINERAL AREA ANALYZED AT LOW MAG NUMBER OF FRAMES AT HIGH MAG NUMBER OF FRAMES AT INTERMEDIATE MAG NUMBER OF FRAMES AT LOW MAG TOTAL NUMBER OF POINTS ANALYZED NUMBER OF POINTS UNDER THRESHOLD

$\begin{array}{rr}= & 3609.6 \\ = & 640423.3 \\ = & 31989.4 \\ = & 359898.6 \\ = & 202309.1 \\ = & 67 \\ = & 99 \\ = & 48 \\ = & 2251 \\ = & 47\end{array}$

WEIGHT PERCENT ON A MINERAL BASIS

\begin{tabular}{|c|c|c|c|c|c|c|c|}
\hline 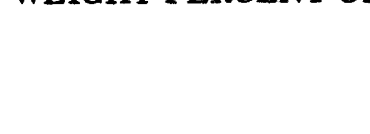 & $\begin{array}{l}1.0 \\
\text { TO } \\
2.2\end{array}$ & $\begin{array}{c}2.2 \\
\text { TO } \\
4.6\end{array}$ & $\begin{array}{c}4.6 \\
\text { TO } \\
10.0\end{array}$ & $\begin{array}{c}10.0 \\
\text { TO } \\
22.0\end{array}$ & $\begin{array}{c}22.0 \\
\text { TO } \\
46.0\end{array}$ & $\begin{array}{c}46.0 \\
\text { TO } \\
100.0\end{array}$ & TOTALS \\
\hline QUARTZ & 15.4 & 6.6 & 2.4 & 4.1 & 4.2 & 2.2 & 34.8 \\
\hline IRON OXIDE & .8 & .0 & .0 & .2 & .0 & .0 & 1.0 \\
\hline \& «RICLASE & .0 & .0 & .0 & .1 & .0 & .0 & .1 \\
\hline P.UTHE & .0 & .4 & .0 & .0 & .1 & .0 & .5 \\
\hline ALUMINA & .0 & .0 & .0 & .0 & .0 & .0 & .0 \\
\hline CALCITE & .0 & .0 & .1 & .0 & .2 & .0 & 3 \\
\hline DOLOMITE & .0 & .7 & .6 & .1 & .0 & .0 & 1.4 \\
\hline ANKERITE & .0 & .0 & .0 & .0 & .0 & .0 & .0 \\
\hline KAOLINITE & .2 & .3 & .3 & .4 & .8 & .7 & 2.6 \\
\hline MONTMORILLONITE & .1 & .1 & .0 & .0 & .2 & .0 & .4 \\
\hline K AL-SILICATE & .0 & .0 & .0 & .1 & .1 & .0 & .2 \\
\hline FE AL_SILICATE & .0 & .0 & .1 & .1 & .0 & .4 & .5 \\
\hline CA AL-SILICATE & 3.4 & 2.4 & 1.6 & 2.0 & 1.2 & .5 & 11.0 \\
\hline NA AL-SILICATE & .3 & .1 & .3 & .8 & .2 & .0 & 1.8 \\
\hline ALUMINOSILICATE & .1 & .0 & .1 & .0 & .4 & .0 & .6 \\
\hline MIXED AL-SILICA & 3 & .4 & .0 & .8 & .1 & .0 & 1.7 \\
\hline FE SחICATE & .1 & .0 & .0 & .0 & .0 & .0 & .1 \\
\hline CA SLICATE & 1.0 & .9 & .7 & 1.3 & .7 & .7 & 5.2 \\
\hline CA ALUMINATE & .8 & 1.5 & 2.4 & 1.3 & .2 & .0 & 6.2 \\
\hline PYRITE & .0 & .0 & .0 & .0 & .0 & .0 & .0 \\
\hline PYRRHOTITE & .0 & .0 & .0 & .0 & .0 & .0 & .0 \\
\hline OXIDIZED PYRRHO & .1 & .0 & .0 & .0 & .0 & .0 & .1 \\
\hline GYPSUM & .0 & .0 & .0 & .0 & .0 & .0 & .0 \\
\hline BARITE & .0 & .0 & .0 & .0 & .0 & .0 & .0 \\
\hline APATITE & .0 & .0 & .0 & .0 & .0 & .0 & .0 \\
\hline CA AL-P & .0 & .2 & .0 & .0 & .1 & .0 & .3 \\
\hline $\mathrm{KCL}$ & .0 & .0 & .0 & .0 & .0 & .0 & .0 \\
\hline GYPSUM/BARITE & .0 & .0 & .0 & .0 & .0 & .0 & .0 \\
\hline GYPSUM/AL-SILIC & .8 & .6 & .2 & .0 & .0 & .0 & 1.7 \\
\hline SI-RICH & .3 & .4 & .4 & .3 & .2 & .2 & .7 \\
\hline CA-RICH & .1 & .2 & .6 & .6 & .3 & .2 & 1.9 \\
\hline CA-SI RICH & .0 & .3 & .0 & .2 & .3 & .2 & 1.1 \\
\hline UNKNOWN & 7.7 & 6.7 & 4.3 & 3.5 & 2.0 & .4 & 24.6 \\
\hline TOTAL & 31.5 & 21.8 & 14.2 & 15.7 & 11.4 & 5.3 & 100.0 \\
\hline
\end{tabular}


TABLE 6

Summary of CCSEM Results - Fly Ash \#3

SUMMARY OF PARAMETERS

TOTAL MINERAL AREA ANALYZED AT HIGH MAG NORMALIZED AREA ANALYZED AT HIGH MAG MINERAL AREA ANALYZED INTERMEDIATE MAG NORMALIZED AREA ANALYZED INTERIMEDIATE MAG TOTAL MINERAL AREA ANALYZED AT LOW MAG NUMBER OF FRAMES AT HIGH MAG NUMBER OF FRAMES AT INTERMEDLATE MAG NUMBER OF FRAMES AT LOW MAG TOTAL NUMBER OF POINTS ANALYZED NUMBER OF POINTS UNDER THRESHOLD

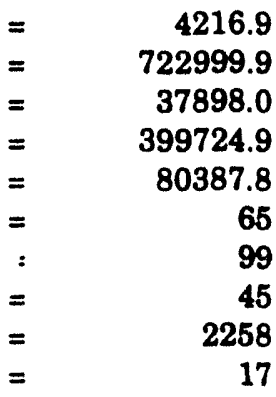

WEIGHT PERCENT ON A MINERAL BASIS

\begin{tabular}{|c|c|c|c|c|c|c|c|}
\hline & $\begin{array}{l}1.0 \\
\text { TO } \\
2.2\end{array}$ & $\begin{array}{l}2.2 \\
\text { TO } \\
4.6\end{array}$ & $\begin{array}{l}4.6 \\
\text { TO } \\
10.0\end{array}$ & $\begin{array}{l}10.0 \\
\text { TO } \\
22.0\end{array}$ & $\begin{array}{l}22.0 \\
\text { TO } \\
46.0\end{array}$ & $\begin{array}{l}46.0 \\
\text { TO } \\
100.0\end{array}$ & TOTALS \\
\hline QUARTZ & 15.2 & 12.6 & 2.6 & 2.0 & 1.2 & .0 & 33.7 \\
\hline IRON OXIDE & .3 & .0 & .1 & .0 & .0 & .0 & .4 \\
\hline PERICLASE & .0 & .0 & .0 & .0 & .0 & .0 & .0 \\
\hline RUTHE & .0 & .0 & .0 & .4 & .0 & .0 & .4 \\
\hline ALUMINA & .0 & .1 & .0 & .0 & .0 & .0 & .1 \\
\hline CALCITE & .0 & .1 & .5 & .4 & .2 & .0 & 1.2 \\
\hline DOLOMITE & .1 & .1 & .5 & .1 & .0 & .0 & .8 \\
\hline ANKERITE & .0 & .0 & .1 & .2 & .0 & .0 & .2 \\
\hline KAOLINITE & .1 & .0 & .0 & .2 & .1 & .0 & .4 \\
\hline MONTMORILLONITE & .0 & .0 & .0 & .0 & .0 & .0 & .0 \\
\hline K AL-SILICATE & .0 & .0 & .0 & .2 & .0 & .0 & .2 \\
\hline FE AL-SILICATE & .0 & .0 & .0 & .0 & .0 & .0 & .0 \\
\hline CA AL_SILICATE & 2.0 & 3.5 & 3.4 & 3.6 & 1.2 & .0 & 13.7 \\
\hline NA AL_SILICATE & .0 & .0 & .0 & .1 & .0 & .0 & .1 \\
\hline ALUMINOSILICATE & .0 & .0 & .0 & .2 & .0 & .2 & .4 \\
\hline MIXED AL SILICA & .1 & .2 & .0 & .0 & .1 & .0 & .4 \\
\hline FE SILICATE & .0 & .0 & .0 & .0 & .0 & .0 & .0 \\
\hline CA SILICATE & .5 & .7 & 1.1 & 1.9 & .6 & .0 & 4.8 \\
\hline CA ALUMINATE & .5 & 1.2 & .7 & .6 & .1 & .0 & 3.1 \\
\hline PYRITE & .0 & .0 & .0 & .0 & .0 & .0 & .0 \\
\hline PYRRHOTITE & .0 & .0 & .1 & .0 & .0 & .0 & .1 \\
\hline OXIDIZED PYRRHO & .0 & .0 & .0 & .0 & .0 & .0 & .0 \\
\hline GYPSUM & .1 & .1 & .1 & .0 & .0 & .0 & .4 \\
\hline BARITE & .0 & .0 & .0 & .0 & .0 & .0 & .0 \\
\hline APATITE & .0 & .0 & .0 & .0 & .0 & .0 & .0 \\
\hline CA AL-P & .0 & .0 & .0 & .0 & .0 & .0 & .0 \\
\hline KCL & .0 & .0 & .0 & .0 & .0 & .0 & .0 \\
\hline GYPSUM/BARITE & .0 & .0 & .0 & .0 & .0 & .0 & .0 \\
\hline GYPSUM/AL-SIIIC & 2.3 & 2.1 & .5 & .7 & .2 & .2 & 6.0 \\
\hline SI-RICH & .3 & .7 & .4 & .4 & .1 & .0 & 1.9 \\
\hline CA-RICH & .0 & .1 & .5 & .3 & .3 & .0 & 1.2 \\
\hline CA-SI RICH & .2 & .2 & .1 & .6 & .3 & .0 & 1.3 \\
\hline UNKNOWN & 8.2 & 8.1 & 5.6 & 5.5 & 1.1 & .7 & 29.2 \\
\hline TOT & 30.0 & 29.8 & 16.2 & 17.3 & 5.6 & 1.0 & 100.0 \\
\hline
\end{tabular}


TABLE 7

Summary of CCSEM Results - Fly Ash \#4

SUMMARY OF PARAMETERS

TOTAL MINERAL AREA ANALYZED AT HIGH MAG

NORMALIZED AREA ANALYZED AT HIGH MAG

$=\quad 4126.0$

MINERAL AREA ANALYZED INTERMEDIATE MAG

NORMALIZED AREA ANALYZED INTERMEDIATE MAG

$=656872.6$

$=\quad 29523.8$

TOTAL MINERAL AREA ANALYZED AT LOW MAG

NUMBER OF FRAMES AT HIGH MAG

NUMBER OF FRAMES AT INTERMEDIATE MAG

NUMBER OF FRAMES AT LOW MAG

TOTAL NUMBER OF POINTS ANALYZED

$=\quad 311399.0$

$=\quad 108515.5$

$=70$

$=99$

$=\quad 45$

NUMBER OF POINTS UNDER THRESHOLD

$=\quad 2151$

WEIGHT PERCENT ON A MINERAL BASIS

$\begin{array}{lllllll}1.0 & 2.2 & 4.6 & 10.0 & 22.0 & 46.0 & \\ \text { TO } & \text { TO } & \text { TO } & \text { TO } & \text { TO } & \text { TO } & \text { TOTALS } \\ 2.2 & 4.6 & 10.0 & 22.0 & 46.0 & 100.0 & \end{array}$

\begin{tabular}{|c|c|c|c|c|c|c|c|}
\hline QUARTZ & 13.7 & 6.4 & 1.6 & 2.0 & 3.2 & .4 & 27.2 \\
\hline IRON OXIDE & .4 & .6 & .2 & .8 & .0 & .0 & 2.0 \\
\hline PERICLASE & .0 & .0 & .0 & .0 & .0 & .0 & .0 \\
\hline RUTாE & .0 & .0 & .0 & .0 & .0 & .0 & .0 \\
\hline ALUMINA & .0 & .0 & .0 & .0 & .0 & .0 & .0 \\
\hline CALCITE & .0 & .0 & .0 & .0 & .0 & .0 & .0 \\
\hline DOLOMITE & .1 & .0 & .5 & .1 & .0 & .0 & .7 \\
\hline ANKERITE & .0 & .0 & .0 & .0 & .0 & .0 & .0 \\
\hline KAOLINITE & .2 & .2 & .2 & .8 & .5 & .2 & 2.1 \\
\hline MONTMORILLONITE & .0 & .1 & .0 & .0 & .0 & .0 & .2 \\
\hline K AL-SILICATE & .0 & .0 & .0 & .0 & .1 & .0 & .1 \\
\hline FE AL_SILICATE & .0 & .0 & .0 & .0 & .0 & .0 & .0 \\
\hline CA AL_SILICATE & 1.1 & 1.6 & .7 & .4 & 1.0 & .0 & 4.9 \\
\hline NA AL_SILICATE & .8 & 1.1 & 1.5 & 1.5 & .7 & .0 & 5.7 \\
\hline ALUMINOSILICATE & .0 & .0 & .0 & .0 & .5 & .0 & .6 \\
\hline MIXED AL-SUICA & .4 & .4 & .2 & .0 & .2 & .0 & 1.2 \\
\hline FE SILICATE & .1 & .0 & .0 & .0 & .0 & .0 & .1 \\
\hline CA SILICATE & .0 & .4 & .2 & .2 & .3 & .0 & 1.1 \\
\hline CA ALUMINATE & .6 & 2.9 & 3.2 & 2.0 & .1 & .0 & 8.7 \\
\hline PYRITE & .0 & .0 & .0 & .0 & .0 & .0 & .0 \\
\hline PYRRHOTITE & .0 & .0 & .0 & .0 & .0 & .0 & .0 \\
\hline OXIDIZED PYRRHO & .0 & .0 & .0 & .0 & .0 & .0 & .0 \\
\hline GYPSUM & .1 & .3 & .1 & .0 & .0 & .0 & .5 \\
\hline BARITE & .0 & .0 & .1 & .0 & .0 & .0 & .1 \\
\hline APATITE & .0 & .0 & .0 & .0 & .0 & .0 & .0 \\
\hline CA AL-P & .0 & .0 & .0 & .0 & .0 & .0 & .0 \\
\hline KCL & .0 & .0 & .0 & .0 & .0 & .0 & .0 \\
\hline GYPSUM/BARITE & .0 & .0 & .0 & .0 & .0 & .0 & .0 \\
\hline GYPSUM/AL-SILIC & 1.5 & 1.6 & .3 & .3 & .1 & .0 & 3.8 \\
\hline SI-RICH & .5 & 1.0 & .4 & .8 & .2 & .0 & 2.9 \\
\hline CA-RICH & .1 & .0 & .2 & .5 & .0 & .0 & .7 \\
\hline CA-SI RICH & .0 & .3 & .2 & .4 & .1 & .0 & 1.0 \\
\hline UNKNOWN & 11.5 & 12.6 & 5.4 & 4.6 & 2.4 & .0 & 36.5 \\
\hline TOTALS & 31.3 & 29.5 & 14.9 & 14.4 & 9.3 & .6 & 100.0 \\
\hline
\end{tabular}


statistically valid the data becomes. Of most importance is the table which summarizes the weight per cent on a mineral basis. These data relate particle size to chemistry. The first column on the left lists the minerals or important chemical relationships defined in the program. The first column of numbers on the left shows the normalized weight percent of the minerais or phases tested for in the size range of 1.0 to 2.2 micrometers. For example, in Table 4, 21.5\% of the particles analyzed were of the size between 1.0 to 2.2 microns. The phase calcium aluminum-silicate was identified the most often in this range $(6.7 \mathrm{wt} \%)$. The unknown portion was next at $6.4 \mathrm{wt} \%$. The unknown category simply means that the chemical analyses of the particle did not match any of the criteria set for those phases listed. This is common for ash analyses with large amounts of amorphous material that can have an extremely variable chemical composition. The raw data can be reviewed for those phases identified as unknown and new phases can be searched for. In addition, it is possible for two or more phases to be analyzed at once using this technique. Review of the raw data can potentially clarify this scenario. This can happen when two separate phased particles are adjacent to each other and both are analyzed at the same time. Agglomerated particles tend to be classified as unknowns for this reason. The rest of the columns give the weight percent of each phase found in that size range. The "Totals" column on the far right gives the weight percent sum of the particles for each mineral phase. This is normalized to $100 \%$, meaning all of the particles analyzed make up $100 \%$ of the sample.

The results presented here will also be placed in the Coal Ash Properties Database in the format shown here. During 1993-1994, preliminary statistical evaluations of these results will be made.

\section{Determination of Types and Causes of Efflorescence in Regional Concrete Products}

The primary objective of this task is to determine specifically what causes efflorescence and if the addition of high-calcium fly ash or other materials can reduce or alleviate the occurrence in concrete products. Additionally, it will be determined if quality control monitoring of ingredients in various mixes can be used to eliminate contaminated or nonspecification materials to avoid contamination-induced efflorescence, which has been suspected as the cause in several documented cases.

Samples of concrete block exhibiting efflorescence were submitted for analysis to determine the composition of the efflorescing materials. Samples were analyzed by XRD and scanning electron microscopy (SEM). Initial XRD results indicated calcite $\left(\mathrm{CaCO}_{3}\right)$. Examination of the same material by SEM showed the crystal forms to be platelets, and the chemical analysis from the microprobe indicated portlandite $\left(\mathrm{Ca}[\mathrm{OH}]_{2}\right)$. The sample analyzed by SEM was kept in a vacuum desiccator to prevent the portlandite from reacting with atmospheric $\mathrm{CO}_{2}$ and converting to calcite. The sample analyzed by XRD was exposed to atmospheric conditions.

An apparatus was constructed that will allow CARRC researchers to reproduce efflorescence in the laboratory. The apparatus is designed to force water through concrete products, bringing soluble elements to the surface. During the next year, various concrete mixes will be tested, and high-calcium coal fly ash will be used in conjunction with other additives to minimize efflorescence under conditions conducive to efflorescence formation. 


\section{Sulfate Resistance of Fly Ash Concrete: A Literature Review and Evaluation of Research Priorities}

The primary objective of this task is to provide definitive information on the sulfate resistance of fly ash concrete. Conflicting research results and misleading information have been published previously, and this project will identify the most complete and technically sound published information. From this information, research needed to strengthen technical support for the use of fly ash concrete in a sulfate environment will be identified. A white paper defining the scope of work, budget, and timetable and listing bidders to perform the work required will be prepared. This task was funded jointly by the ACAA through the CARRC small projects effort.

Computer and manual literature searches were performed. The literature obtained was reviewed, and discussions were held with consultant Oscar Manz regarding work he had performed in this area with other key research groups. Preparation of the white paper was initiated, and a draft will be submitted to ACAA and CARRC members late in 1993.

\section{ADDITIONAL ACCOMPLISHMENTS}

CARRC researchers and other EERC personnel initiated an effort to provide information to the DOE for a report to Congress on the barriers to the increased utilization of coal combustion and desulfurization by-products by government and commercial sectors. CARRC researchers anticipate the cooperation and input of CARRC members, utilities, the coal ash industry, related industries, and government agencies. The DOE requested that a workshop summarizing the results of the study be held in September, and the EERC will provide a draft report to DOE late in September. The DOE report to Congress is due late in 1993.

As a result of efforts by CARRC researchers and other EERC personnel, the new EERC laboratory addition was constructed with fly ash concrete. Local contractors, engineers, and architects who had not had previous experience with fly ash concrete had the opportunity to be involved in the construction project. CARRC researchers wish to acknowledge and thank STRATA Corporation, especially Mr. Duane Dumas, who supplied the ready-mix fly ash concrete and worked closely with the contractors over the duration of the project. Concrete Incorporated, which manufactured the preformed fly ash concrete sections, is also thanked for their cooperation and support. A second EERC pilot plant addition was also sent out for bids, specifying the use of fly ash concrete. With the cooperation and assistance of Mr. Leroy Sondrol, Director of UND Physical Plant, and Mr. Kevin Knaus, UND Engineer, several fly ash concrete paving projects were planned for various locations around campus during 1993-1994. CARRC researchers worked with UND officials to change specifications to include the use of fly ash in concrete. These changes have been approved and will be implemented for the 1994 construction season.

In 1992, a survey of coal ash utilization in DOE Region 8, funded by the DOE Denver Support Office, was performed under the direction of Ann-Marie Gritzuk, Montana Department of Natural Resources and Conservation - Energy Division. A report of the survey was widely distributed regionally and nationally. Following review of this document, representatives of utilities, coal ash marketers, research groups and state 
agencies met in Bismarck, North Dakota, to discuss ways to advance coal ash use in the region. As a result of this meeting, CARRC researchers prepared a proposal to develop an ash utilization training and promotion effort in DOE Region 8. The proposal was submitted to the Technology Reinvestment Program in June 1993. Announcements of awards was scheduled for December 1993. Additional regional meetings were planned for 1993-1994. CARRC members indicated that the advancement of coal ash utilization in DOE Region 8 would benefit the coal ash industry in general, so CARRC members and researchers plan to participate in this continuing effort. CARRC researchers participation level will be determined on the basis of funds available.

\section{PLANNED ACTIVITIES FOR 1993-1994}

Research objectives for 1993-1994 can be summarized as follows:

- Advance predictive capabilities for ash behavior in utilization applications

- Promote high-volume use applications for coal ash

- Evaluate the potential for environmental impact from coal ash utilization and disposal

- Develop a database of utilization applications requirements

- Investigate advanced technological utilization applications and promote innovative ash use

- Facilitate the production of consistent, quality-assured coal ash

These specific objectives are consistent with the primary goal of CARRC. The research tasks proposed address several generalized research areas. These research areas and research and laboratory tasks can be summarized as follows:

- High-volume fly ash (HVFA) utilization

- Deicing resistance of HVFA concrete

- HVFA concrete in small construction projects

- Quantification of coal ash reactivity

- Application of CCSEM for coal ash characterization

- Development of heat of hydration procedure - Deleted for 1993-1994

- Advanced methods for determination of Mineral Phases in Coal Conversion Solid Residues

- Behavior of coal ash in products

- Efflorescence in concrete products containing high-calcium coal by-products

- Determination of the role of mineral phase formation in long-term stability in products containing advanced coal conversion process residues 
- Investigation of the effect of chemical admixtures on the setting time of fly ash and cement pastes

- Environmental evaluation of coal ash and coal ash products

- Development of environmentally appropriate leaching procedure for coal ash

- Comparative leaching study of coal combustion by-products and competing construction materials - Postponed

- Computer database and software development.

- Expansion of the coal ash properties database

- Generation of the use applications requirements database

\section{LIST OF SELECTED PUBLICATIONS}

The following is a list of citations for selected publications. The complete documents are contained in Appendix A.

Bender, J.A.; Solem, J.K; McCarthy, G.J.; Oseto, M.C.; Knell, J.E. "Quantitative XRD Analysis of Advanced Coal Combustion Solid Residuals by the RIR Method," X-Ray Analysis 1993, 36, in press.

Dockter, B.A.; Moretti, C.J. "Development of Laboratory Methods for Evaluating the Erosion Resistance of Fly Ash-Based Materials," In Proceedings of the 10th International Coal Ash Use Symposium; Orlando, FL, Jan. 18-21, 1993.

Dockter, B.A.; Moretti, C.J. "Fluidized-Bed Combustion Waste: Utilization and Disposal," Presented at the Application of Fluidized-Bed Combustion for Power Generation Conference, Cambridge, MA, Sept. 23-25, 1992.

Erickson, T.A.; O'Leary, E.M.; Folkedahl, B.C.; Ramanathan, M.; Zygarlicke, C.J.; Steadman, E.N.; Hurley, J.P.; Benson, S.A. "Coal Ash Behavior and Management Tools," Presented at the Engineering Foundation Conference, The Impact of Ash Deposition on Coal Fired Plants, Solihull, United Kingdom, June 20-25, 1993.

Manz, O.E. "Worldwide Production of Coal Ash and Utilization in Concrete and other Products," Presented at the American Coal Ash Association 10th International Coal Ash Use Symposium, Orlando, FL, Jan. 1993.

McCarthy, G.J.; Hassett, D.J.; Bender, J.A. "Synthesis, Crystal Chemistry and Stability of Ettringite, A Material with Potential Applications in Hazardous Waste Immubilization," in Advanced Cementitious Systems: Mechanisms and Properties; Materials Research Society Symposium Proceedings Series: 1992; Vol. 245, pp 129-1.10.

Pflughoeft-Hassett, D.F.; Hassett, D.J.; Dockter, B.A. "High-Volume Fly Ash Utilization and the Effects on Groundwater in North Dakota," In Proceedings of the 10th International Coal Ash Use Symposium; Orlando, FL, Jan. 18-21, 1993. 
Solem, J.K.; McCarthy, G.J. "Hydration Reactions and Ettringite Formation in Selected Cementitious Coal Conversion By-Products," in Advanced Cementitious Systems: Mechanisms and Properties; Materials Research Society Symposium Proceedings Series: 1992; Vol. 245.

Strobel, T.M.; Eylands, K.E.; Hassett, D.J.; Docker, B.A.; Pflughoeft-Hassett, D.F.; "Utilization Potentials for Duct Injection Residues, "In Proceedings of the 10th American Coal Ash Association International Coal Ash Use Symposium; Orlando, FL, Jan. 18-21, 1993.

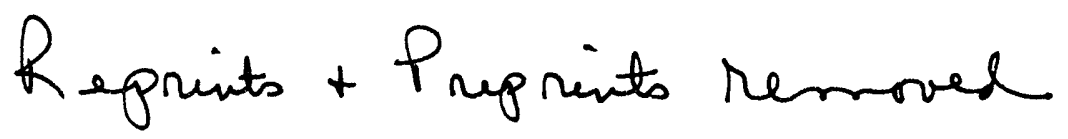

23 

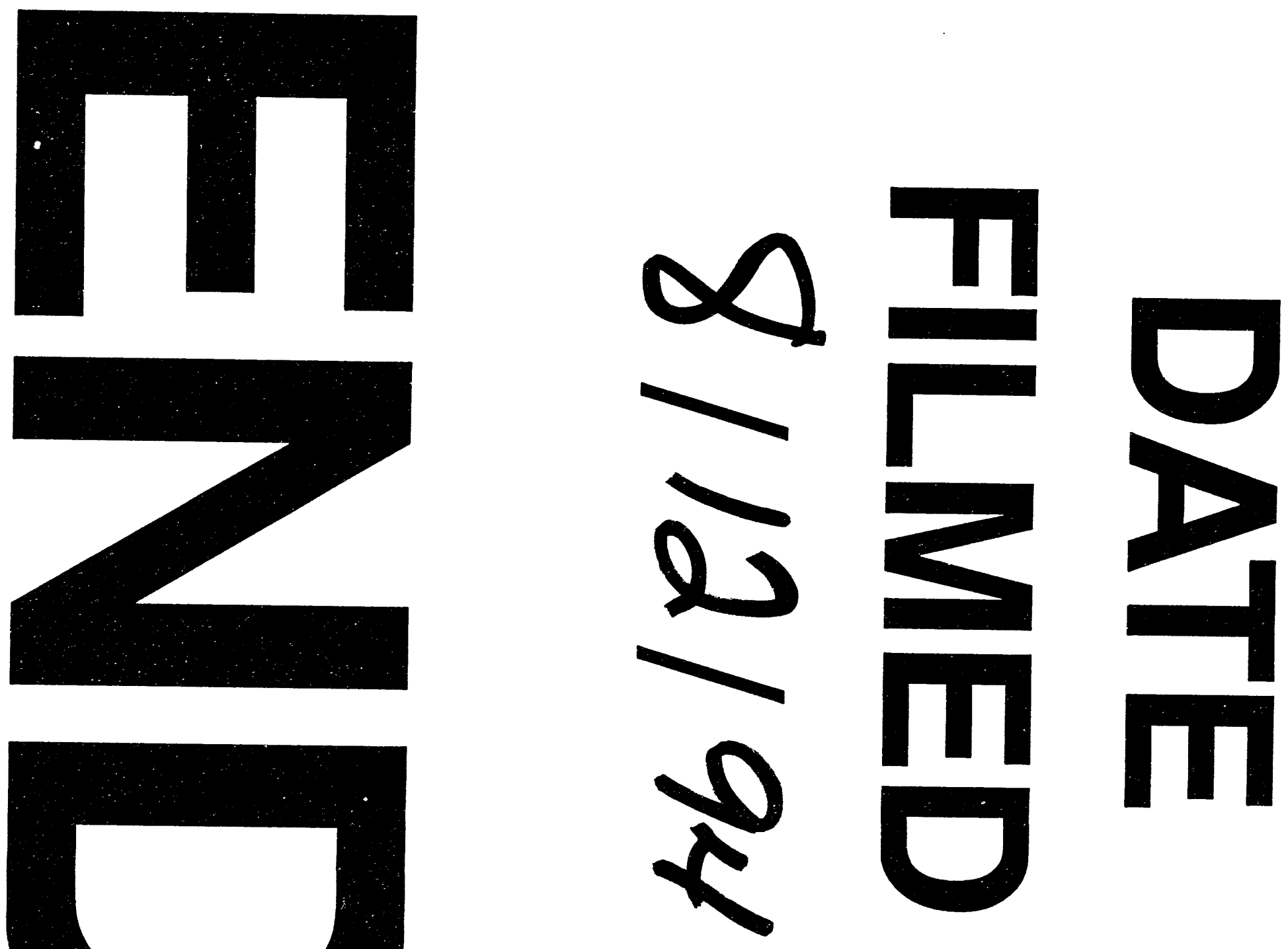

$\underset{D}{0}$
$\stackrel{\rho}{H}$. 


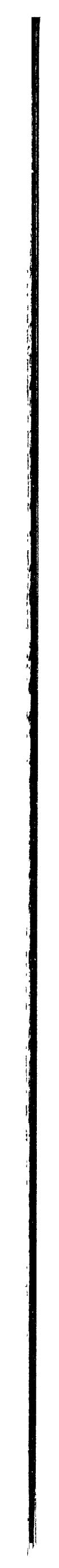

